\title{
EFFECT OF METHOD APPLICATION OF HUMIC ACID COMBINED WITH MINERAL N FERTILIZER ON SOIL FERTILITY AND FABA BEAN PRODUCTIVITY IN SANDY SOIL. \\ Dalia A. Sayed; M. S. Mahrous and Seham Y. M. Abo-Steet Soils, Water and Environment Research Institute, Agric. Res. Centre Giza, (Egypt).
}

\begin{abstract}
A filed experiment was conducted at winter successive two seasons of 2012/2013 and 2013/2014 in the Farm of Ismalia Agriculture Research Station, (ARC), Ismalia Governorate, Egypt, to study the effect of different methods addition of humic acid on soil fertility and faba bean (Sakha 3 ) productivity. The experiment includes two methods of application (soil application at rates of 5 and $10 \mathrm{~kg}$ humic $/ f e d$ ) and foliar application at rates of ( $1 \mathrm{~g}$ and $2 \mathrm{~g}$ humic $/ \mathrm{L}$ water) alone or combined with mineral nitrogen fertilizer at rates of $(0,10,20$ and $30 \mathrm{~kg} \mathrm{~N} / \mathrm{fed})$ as ammonium nitrate $(33.5 \% \mathrm{~N})$. The obtained results indicated that the effect of addition humic acid methods (soil application or foliar application) significantly increased growth character i.e. plant height (cm), No. of branch /plant, No. of pods/plant, weight of pods /plant (g) and weight of seed/plant $(\mathrm{g})$ in both seasons. As well as, the methods used of humic acid (soil application or foliar application) at different rates had a significant effect on of seed yield (ton/fed), pods yield (ton/fed) and weight of 100 seeds (g) and chlorophyll, respectively, while the protein content was no significant in both seasons. Concerning the effect of humic acid application on N, P and $\mathrm{K}$ concentration in seeds were increased with increasing rates of humic $10 \mathrm{~kg} / \mathrm{fed}$ and mineral $\mathrm{N}$ fertilizer $30 \mathrm{~kg}$ $\mathrm{N} / \mathrm{fed}$. The interaction between humic acid methods system application and different rates of mineral $\mathrm{N}$ were significantly increase for $\mathrm{Fe}$ in both seasons but no significant for $\mathrm{Mn}$ and $\mathrm{Zn}$ concentration in seeds faba bean plants. Also, the soil application of humic acid with $10 \mathrm{~kg} / \mathrm{fed}$ and foliar application at a rate of $2 \mathrm{~g}$ humic acid $/ \mathrm{L}$ with $30 \mathrm{~kg}$ $\mathrm{N}$ led to highest available N, P and $\mathrm{K}$ content in soil after faba bean harvest compared with other treatments. On the other hand, the interaction between methods of humic acid application and different rates of mineral $\mathrm{N}$ fertilizer on Fe was significant in the first season and $\mathrm{Mn}$ in both seasons, while $\mathrm{Zn}$ was no significant in both seasons. It can be concluded that soil application of humic acid at rate $10 \mathrm{~kg}$ humic $/ \mathrm{fed}$ and foliar application at rate $2 \mathrm{~g} / \mathrm{L}$ water had a favorable effect on yield and yield component and improve chemical constituents of faba bean and sandy soil.
\end{abstract}

Keywords: humic acid, Faba bean productivity, sandy soil, mineral nitrogen fertilizer.

\section{INTRODUCTION}

Humic acid is a commercial product contains many elements which improve the soil fertility and increasing the availability of nutrient elements and consequently affected plant growth and yield. Humic acid particularly is used to remove or decrease the negative effects of chemical fertilizers and some chemicals from the soil, (Hartwigson and Evans, 2000). Salman et al., (2005) found that the availability of phosphate and iron increased due to humic application. Rajpar et al., (2011) indicated that humic acid efficiently improves soil fertility and crop productivity, especially on poorly fertile soil. Mauromicale et al., (2011) reported that the role of humic acid is well known in controlling, soil-borne diseases and improving soil health and nutrient 
uptake by plants, mineral availability in soil. Mohamed et al., (2009) reported that humic acid stimulate plant enzymes/hormones and improve soil fertility in an ecologically and environmentally benign manner. Darur et al (2008) studied the effect of different rates of nitrogen on dry matter and seed yield of faba bean were significant quadratic relation with the increasing $\mathrm{N}$ rates. Hamid et al., (2011) reported that the without nitrogen fertilizer led to decreased values of seeds yield, plant height, 100 seed (g), No. of pod/plant and No. of seed/plant respectively. Prusiński (2007) reported that soil application with $30-90 \mathrm{~kg} \mathrm{~N} / \mathrm{ha}$ as urea resulted in a significant increase in yield parameters, $\mathrm{N}$ concentration, and $\mathrm{N}$ uptake of faba bean plants. Maral (2012) indicated that interaction effect of humic acid and nitrogen management on seed yield, straw yield and harvest index showed significant differences at $5 \%$ probability level.

Faba bean (Vicia faba L.) is an important legume crop in Egypt and many parts of the world. It is popular food as it is used as green vegetable or fresh canned. Also, it is an important crop for soil improvement and is used as crop in cereal rotation to keep the soil fertile and productive through nitrogen fixation, (Mohammad et al., 2011). Egyptian Government is pressing hard to increase the yield and quality of faba bean plant through improving agricultural practices such as fertilization to face the increasing demand of the population,(Ahmed et al 2003). Faba bean (Vicia faba L.) is an important legume crop in Egypt and many parts of the world. Its seeds exhibit high levels of protein (28-36\% of seed dry matter), (El-Kotb, 2013). Kocon (2010) found that broad bean yield increased by $14-15 \%$ when spraying with urea, compared to $2.4 \%$ at ground fertilization. Atere and Olayinka (2012) found that the low $\mathrm{pH}$ value obtained with the inorganic fertilizer application might be due to the acid-yielding property of urea fertilizer that served as the source of starter N. Bloom (2000) found that the ureasemediated reaction of soil-applied urea with $\mathrm{H}_{2} \mathrm{O}$ results in rapid conversion to $\mathrm{NH}_{4}{ }^{+}$. In this reaction, $\mathrm{H}^{+}$ions are consumed and $\mathrm{NH}_{4}{ }^{+}$and $\mathrm{HCO}_{3}^{-}$are produced, causing the soil $\mathrm{pH}$, at the reaction site to increase. Adeyeye et al (2014) indicated that the application of $\mathrm{N}$ - fertilizer had no significant effect on all the growth parameters of soybean such as numbers of pods, number of seeds, seed weight and grain yield. Ahmed and Yassin (2013) stated that nitrogen plays an important role in plant growth and physiological processes, as it enters in all enzymes composition and enhances vegetative growth and yield.

The of this study investigate the growth, yield and components of faba bean plants and soil fertility as affect by soil application and foliar application of humic acid methods alone or combined with different mineral nitrogen rates fertilizer under sandy soil conditions.

\section{MATERIALS AND METHODS}

Two filed experiments were conducted at winter successive two seasons of 2012/2013 and 2013/2014 in the Farm of Ismalia Agriculture Research Station, (ARC), Ismalia Governorate, Egypt. The experiments were carried out to study the effect of methods of humic acid addition or foliar 
combined with different rates of mineral nitrogen fertilizer on some macromicronutrients in soil, faba bean productivity and macro-micronutrients concentration in seeds of faba bean (Vicia faba L.) variety Sakha 3. The experiment was laid out in a randomized complete block design with three replicates. The experiment was divided into two divisions; the first part was treated with humic acid mixed with sandy soil application for two rates at 5 and $10 \mathrm{~kg}$ humic acid mixed with $100 \mathrm{~kg}$ sandy soil. The applied of humic acid in same seedling plants day. Also, the second division was treated with humic acid foliar application for two rates of 1 and $2 \mathrm{~g} / \mathrm{L}$ as well as foliar application after 21,45 and 65 days after seeds sowing. Nitrogen fertilizer was added as ammonium nitrate $(33.5 \% \mathrm{~N})$ with four rates $(0,10,20$ and 30 $\mathrm{kg} \mathrm{N} \mathrm{fed}^{-1}$ ) in three times 21, 45 and 65 days after seeds planting.

Some physical and chemical properties of the experimental soil were shown in Table (1) according to Page et al (1982) and Cottenie et al., (1982).

Table (1) Some physical and chemical properties of the studied soil before planting:

\begin{tabular}{|c|c|c|c|c|c|c|c|c|}
\hline $\begin{array}{c}\text { Coarse } \\
\text { sand } \\
(\%)\end{array}$ & $\begin{array}{c}\text { Fine sand } \\
(\%)\end{array}$ & $\begin{array}{l}\text { Silt } \\
\text { (\%) }\end{array}$ & $\begin{array}{l}\text { Clay } \\
(\%)\end{array}$ & \multicolumn{2}{|c|}{ Soil Texture } & \multicolumn{2}{|c|}{$\begin{array}{l}\text { OM } \\
(\%)\end{array}$} & $\begin{array}{c}\mathrm{CaCO}_{3} \\
(\%)\end{array}$ \\
\hline 10.67 & 75.64 & 4.86 & 8.83 & \multicolumn{2}{|c|}{$\begin{array}{l}\text { Loamy } \\
\text { sand }\end{array}$} & \multicolumn{2}{|c|}{0.55} & 1.68 \\
\hline \multirow{2}{*}{$\mathrm{pH}(1: 2.5)$} & \multirow{2}{*}{\begin{tabular}{|c|}
$\mathrm{EC}^{*}$ \\
$\left(\mathrm{dSm}^{-1}\right)$
\end{tabular}} & \multicolumn{4}{|c|}{ Cations (meq/l) } & \multicolumn{3}{|c|}{ Anions $(\mathrm{meq} / \mathrm{l})$} \\
\hline & & $\mathrm{Ca}^{++}$ & $\mathrm{Mg}^{++}$ & $\mathrm{Na}^{+}$ & $\mathrm{K}^{+}$ & $\mathrm{HCO}_{3}^{-}$ & $\mathrm{Cl}^{-}$ & $\mathrm{SO}_{4}^{-1}$ \\
\hline 8.03 & 1.79 & 4.58 & 2.44 & 10.13 & 0.75 & 2.85 & 6.37 & 8.68 \\
\hline \multicolumn{3}{|c|}{ Available macronutrients $(\mathrm{mg} / \mathrm{kg}$ ) } & \multicolumn{6}{|c|}{ Available micronutrients $(\mathrm{mg} / \mathrm{kg})$} \\
\hline $\mathrm{N}$ & $\mathrm{P}$ & $\mathrm{K}$ & $\mathrm{Fe}$ & $\mathrm{Mn}$ & & \multicolumn{3}{|c|}{$\mathrm{Zn}$} \\
\hline 37.95 & 3.55 & 182 & 1.38 & 1.35 & & \multicolumn{3}{|c|}{0.49} \\
\hline
\end{tabular}

All farming processes were carried out before planting. Super phosphate $\left(15.5 \% \mathrm{P}_{2} \mathrm{O}_{5}\right)$ was applied ate a rate of $100 \mathrm{~kg}$ super phosphate fed $^{-1}$ during tillage of soil. Seeds of faba bean were sown in 21 November in both seasons. Each experimental plot unit was $50 \mathrm{~m}^{2} / \mathrm{fed}(5 \mathrm{~m}$ width and 10 $\mathrm{m}$ long) at row to row distance of $50 \mathrm{~cm}$. Two to three of seeds were sown in holes was $20 \mathrm{~cm}$. After 21 day of sowing, the plants of each hole were thinned to one plant. Potassium sulphate $\left(48 \% \mathrm{~K}_{2} \mathrm{O}\right)$ was applied at a rate of $50 \mathrm{~kg}$ fed $^{-1}$ on two equal doses after 20 and 40 days from sowing.

Soil samples were collected from all studied treatments at a depth of $(0-30 \mathrm{~cm})$ to determine some soil physical and chemical characteristics. Soil $\mathrm{pH}$ was determined in 1:2.5 soil: water suspensions according to the standard method of Richards (1954). Total soluble salts were measured in soil paste extract as described by Jackson (1973). Nitrogen was determined by kjeldahl method (Page et al, .1982). Phosphorus was determined colorimetrically and potassium was determined using flame- photometer according to Jackson (1973). Available micronutrients were extracted by DTPA (Soltanpour and Schwab 1977) and determined using Atomic Absorption Spectrophotometer. 
Plant analysis : samples of faba bean seeds were oven dried at 70Co, crushed then wet ashed using of $\mathrm{H}_{2} \mathrm{SO}_{4}+\mathrm{HCLO}_{4}$ acids, then in aliquots of digested solution, $\mathrm{P}, \mathrm{K}, \mathrm{Fe}, \mathrm{Mn}$ and $\mathrm{Zn}\left(\mathrm{mg} \mathrm{kg}^{-1}\right)$, were determined (Soltanpoure, 1985). Total $\mathrm{N}$ content in seeds was determined by using micro-kjeldhl and protein was calculated by multiplying $\mathrm{N}$ content by 6.25 according to Chapman and Pratt (1961). Protein percentage of seeds was calculated by multiplying the nitrogen percentage by the factor 6.25 described by Hymowitz, et al (1972).

Random samples of ten plants were collected at 70 days after sowing from each plot to measure total chlorophyll. Photosynthetic total chlorophyll was estimated in fresh leaves as described by Witham et al. (1971).

All the data were subjected to an analysis of variance using the statistical analysis method described by Snedecor and Cochran (1990).

\section{RESULTSAND DISCUSSION}

\section{Effect of methods application of humic acid on faba bean plants characters in sandy soil:}

Effect of humic acid added at a rates of (5 and $10 \mathrm{~kg} / \mathrm{fed}$ ) and foliar (liquid 1 and $2 \mathrm{~g}$ humic acid/L water) on plant height $(\mathrm{cm})$ No. of branches /plant, No. of pods/plant, weight of pods /plant (g) and weight of seeds/plant (g) in both seasons are shown in Table 2. The highest mean values of all growth characters are obtained with soil treated with humic acid application by $10 \mathrm{~kg}$ humic acid /fed combined with $30 \mathrm{~kg} \mathrm{~N} / \mathrm{fed}$. Also, the relative increases of mean values are 9.18, 8.80, 10.10, 9.38, 3.81, 6.73, 13.76, $14.49,6.22$ and $7.21 \%$ for plant height $(\mathrm{cm})$, No. of branches /plant, No. of pods/plant, weight of pods /plant (g) and weight of seeds/plant (g), respectively for soil application of humic acid with $10 \mathrm{~kg}$ compared with $5 \mathrm{~kg}$ humic acid/fed. On the other hand, the highest mean values of plant height $(\mathrm{cm})$, No. of branches /plant, No. of pods/plant, weight of pods /plant $(\mathrm{g})$ and weight of seeds/plant $(\mathrm{g})$ in plots treated with $2 \mathrm{~g}$ humic $/ \mathrm{L}$ in both seasons. The corresponding relative increase of mean values were 1.38, 1.32, 10.00, $1.60,4.51,9.90,13.89$ and $9.57 \%$ for plant height $(\mathrm{cm})$, No. of branches /plant, No. of pods/plant, weight of pods /plant (g) and weight of seeds/plant (g), respectively, as affected plant treated with foliar application (liquid ) $2 \mathrm{~g} / \mathrm{L}$ compared with $1 \mathrm{~g} / \mathrm{L}$. The addition of humic acid significantly, (soil application or foliar application) increased all the studied growth characters i.e. plant height $(\mathrm{cm})$, No. of branches /plant, No. of pods/plant, weight of pods/plant (g) and weight of seeds/plant (g) in both seasons. Meanwhile, the different mineral nitrogen rates were significantly increased all plant growth characters except No. of branches /plant in the first seasons and No. of pods/plant in the second season.

Concerning the interaction between methods of humic acid application and different rates of mineral nitrogen were significant increase on plant height and No. of pods/plant in both seasons, except No. of branch was no significant in first season and weight of pods /plant $(\mathrm{g})$ in the second season as well as the effect of interaction between humic acid methods and 
different rates of mineral $\mathrm{N}$ fertilizer were no significant on the weight of seeds/plant $(\mathrm{g})$ in both seasons.

Table 2. Effect of methods of humic acid application combined with different rates of $\mathbf{N}$ fertilization on plant growth .

\begin{tabular}{|c|c|c|c|c|c|c|c|c|c|c|c|}
\hline \multirow[t]{2}{*}{ Treatments } & \multirow{2}{*}{$\begin{array}{c}\text { Rates } \\
\text { of } N \\
\text { kg } \\
\text { fed }^{-1}\end{array}$} & \multicolumn{2}{|c|}{$\begin{array}{c}\text { Plant } \\
\text { height } \\
(\mathrm{cm})\end{array}$} & \multicolumn{2}{|c|}{$\begin{array}{c}\text { No. of } \\
\text { branches/plant }\end{array}$} & \multicolumn{2}{|c|}{$\begin{array}{l}\text { No. of } \\
\text { pods / } \\
\text { plant }\end{array}$} & \multicolumn{2}{|c|}{$\begin{array}{l}\text { Weight of } \\
\text { pods } \\
\text { /plant } \\
\text { (g) }\end{array}$} & \multicolumn{2}{|c|}{$\begin{array}{l}\text { Weight of } \\
\text { seeds } \\
\text { /plant (g) }\end{array}$} \\
\hline & & $1^{\text {st }}$ & $2^{\text {nd }}$ & 15 & $2^{\text {nd }}$ & $1^{\text {st }}$ & $2^{\text {nd }}$ & $1^{\text {st }}$ & $2^{\text {nd }}$ & $1^{\text {st }}$ & $2^{\text {nd }}$ \\
\hline \multirow{4}{*}{$\begin{array}{l}5 \mathrm{~kg} / \mathrm{fed} \\
\text { humic acid }\end{array}$} & 0 & 55.37 & 56.17 & 3.45 & 58 & 8.35 & 8.45 & 25.63 & 26.49 & 22.47 & 2.57 \\
\hline & 10 & 64.85 & 68.21 & 4.5 & 4.66 & 9.72 & 9.78 & 28.41 & 30.52 & 23 & 23.86 \\
\hline & 20 & 73.29 & 75.49 & 5.18 & 5.38 & 10.48 & 10.86 & 33.48 & 34.98 & 24. & 24.55 \\
\hline & 30 & 77.10 & 78.36 & 6.25 & 6.42 & 11.35 & & 34.29 & 36.10 & 24 & 24.96 \\
\hline \multicolumn{2}{|l|}{ Mean } & 67.65 & 69.56 & 4.85 & 5.01 & 9.98 & 10.26 & 30.45 & 32.02 & 23 & 23.99 \\
\hline \multirow{4}{*}{$\begin{array}{l}10 \mathrm{~kg} / \mathrm{fed} \\
\text { humic acid }\end{array}$} & 0 & 55.86 & 56.93 & 3.78 & 3.75 & 8.66 & 8.79 & 27.55 & 30.28 & 23 & 23.54 \\
\hline & 10 & 73.98 & 77.39 & 4.88 & 4.95 & 9.89 & 10.55 & 34.29 & 35.66 & 24 & 24.94 \\
\hline & 20 & 79.48 & 80.22 & 5.68 & 5.88 & 10.55 & 11.63 & 36.21 & 38.52 & 26 & 26.75 \\
\hline & 30 & 86.10 & 88.19 & 7.00 & 7.32 & 12.34 & 12.84 & 40.52 & 42.19 & 27. & 27.66 \\
\hline \multicolumn{2}{|l|}{ Mean } & 73.86 & 75.68 & 5.34 & 5.48 & 10.36 & 10.95 & 34.64 & 36.66 & 25 & 25.72 \\
\hline \multirow{4}{*}{$1 \mathrm{~g} / \mathrm{L}$} & 0 & 55.78 & 56.82 & 3.41 & 3.52 & 6.75 & 6.88 & 24.10 & 24.74 & 21 & 21.66 \\
\hline & 10 & 70.26 & 71.33 & 4.39 & 5.14 & 7.39 & 7.95 & 28.36 & 30.62 & 22 & 22.89 \\
\hline & 20 & 72.93 & 73.46 & 4.90 & 5.49 & 7.86 & 8.04 & 30.59 & 31.16 & 23.18 & 23.55 \\
\hline & 30 & 73.64 & 74.69 & 5.68 & 6.12 & 8.00 & 8.15 & 33.29 & 33.85 & 23.66 & 23.87 \\
\hline \multicolumn{2}{|l|}{ Mean } & 68.15 & 69.08 & 4.60 & 5.07 & 7.50 & 7.76 & 29.09 & 30.09 & 22.75 & 22.99 \\
\hline \multirow{4}{*}{$2 \mathrm{~g} / \mathrm{L}$} & 0 & 55.93 & 56.88 & 3.56 & 3.60 & 6.79 & 7.21 & 26.39 & 29.41 & 23. & 23.75 \\
\hline & 10 & 71.43 & 72.86 & 4.88 & 5.12 & 7.58 & 7.88 & 30.55 & 33.51 & 24. & 24.86 \\
\hline & 20 & 73.59 & 74.21 & 5.36 & 5.88 & 7.98 & 8.34 & 33.69 & 35.22 & 25.85 & 25.99 \\
\hline & 30 & 75.42 & 76.00 & 6.42 & 6.59 & 8.13 & 9.00 & 37.25 & 38.79 & 25.98 & 26.17 \\
\hline \multicolumn{2}{|l|}{ Mean } & 69.09 & 69.99 & 5.06 & 5.30 & 7.62 & 8.11 & 31.97 & 34.23 & 25.00 & 25.19 \\
\hline \multicolumn{2}{|c|}{$\begin{array}{l}\text { L.S.D. } \\
5 \% \text { Methods }\end{array}$} & 1 & 1 & .40 & 0.016 & 0.29 & 2.84 & 85 & 2 & 0.88 & 1.06 \\
\hline \multicolumn{2}{|c|}{ L.S.D. Rate N } & 0.41 & 0.91 & ns & .014 & 0.40 & 110 & 1.74 & 0.94 & 1.80 & 1.03 \\
\hline \multicolumn{2}{|c|}{ Interaction $\mathrm{R}$ XM } & $\star *$ & $\star *$ & ns & ** & $\star *$ & $\star \star$ & 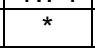 & ns & $\mathrm{ns}$ & ns \\
\hline
\end{tabular}

The relative increases of mean values 3.11 and $4.44 \%$ for plant height; 5.49 and $1.16 \%$ for No. of branches; 34.52 and $33.65 \%$ No. for pods/plant; 6.60 and $6.78 \%$ for weight of pods /plant and 2.83 and $3.18 \%$ for weight of seeds/plant in the first and second seasons respectively as affected by humic acid application methods compared with foliar application method system. These results are in agreement with El-Bassiony et al. (2010) who showed that foliar application by humic acid (at 1,2 or $3 \mathrm{~g} / \mathrm{L}$ ), significantly affected on all the vegetative growth parameters, i.e. plant height, number of leaves and branches as well as fresh and dry weight of whole snap bean plants (Phaseolus vulgaris, L.) Cv. Paulesta grown under sandy soil conditions comparing with control plants. Kaya et al. (2005) mentioned that foliar application of common bean by humic acid at $2000 \mathrm{ml} / \mathrm{ha}$, significantly increased number of seeds/plant and seed weight/plant. 


\section{Effect of different methods of humic acid addition on yield and yield components:}

Data in Table 3 show that the methods used of humic acid (soil application or foliar application) at different rates had a significant effect on seeds yield (ton/fed), pods yield (ton/fed) and weight of 100 seeds $(\mathrm{g})$ and chlorophyll, respectively, while the protein was no significant in both seasons. The highest mean values of seeds yield (ton/fed), pods yield (ton/fed) and weight of 100 seeds $(\mathrm{g})$, protein and chlorophyll were obtained by $10 \mathrm{~kg} / \mathrm{fed}$ humic acid application compared with other treatments. The increase of all parameters of faba bean plants was carried out with the increase of humic acid rate $(10 \mathrm{~kg} / \mathrm{fed})$ application and foliar humic rates of $2 \mathrm{~g} / \mathrm{L}$ combined with increase of mineral nitrogen fertilizer rate. These results are in agreement with Shafeek et al (2013) and Abdel-Razzak and El-Sharkawy (2013) who found that the foliar spraying rates of humic acid $(4 \mathrm{~g} / \mathrm{L})$ recorded the high values of total yield and pods yield of borad bean and could be attributed to presence of plant growth regulators and increased activity of microbes. Antoun et al (2010) reported that application of humic acid in combination with the highest rate of $\mathrm{N}$-fertilizer led to increase values of yield and its components of wheat plant. Results in Table 3 show that the effect of mineral nitrogen fertilization at different rates were significant affected on seeds yield (ton/fed), pods yield (ton/fed), weight of 100 seeds and protein (\%) respectively, while chlorophyll content was no significant in both seasons.

Table (3). Yield and yield components of faba bean

\begin{tabular}{|c|c|c|c|c|c|c|c|c|c|c|c|}
\hline \multirow{2}{*}{ Treatments } & \multirow{2}{*}{$\begin{array}{c}\text { Rates } \\
\text { of } \mathbf{~} \\
\mathbf{k g} \\
\mathrm{fed}^{-1}\end{array}$} & \multicolumn{2}{|c|}{$\begin{array}{l}\text { Seed yield } \\
\text { (ton/fed) }\end{array}$} & \multicolumn{2}{|c|}{$\begin{array}{l}\text { Pods yield } \\
\text { (ton/fed) }\end{array}$} & \multicolumn{2}{|c|}{$\begin{array}{l}\text { Weight of } \\
100 \text { seeds }\end{array}$} & \multicolumn{2}{|c|}{$\begin{array}{l}\text { Protein } \\
(\%)\end{array}$} & \multicolumn{2}{|c|}{$\begin{array}{l}\text { Chlorophyll } \\
(a+b) \mathrm{mg} / \mathrm{g} \\
\text { f.w. }\end{array}$} \\
\hline & & $1^{\text {st }}$ & $2^{\text {nd }}$ & $1^{\text {st }}$ & $2^{\text {nd }}$ & $1^{\text {st }}$ & $2^{\text {nd }}$ & $1^{\text {st }}$ & $2^{\text {nd }}$ & $1^{\text {st }}$ & $2^{\text {nd }}$ \\
\hline \multirow{4}{*}{$\begin{array}{l}5 \quad \mathrm{~kg} / \mathrm{fed} \\
\text { humic acid }\end{array}$} & 0 & 0.472 & 0.472 & 0.761 & 778 & 4.68 & 54.88 & 18.44 & 19.00 & 2.45 & 2.48 \\
\hline & 10 & 0.794 & 0.819 & 0.986 & 0.995 & 56.47 & 57.31 & 20.81 & 22.38 & 3.74 & 3.78 \\
\hline & 20 & \begin{tabular}{|l|}
0.879 \\
\end{tabular} & 0.894 & 1.063 & 1.134 & 59.27 & 59.94 & 21.13 & 22.88 & 3.82 & 3.86 \\
\hline & 30 & 0.918 & 0.961 & 1.149 & 1.185 & 61.43 & 62.10 & 21.44 & 23.19 & 3.98 & 4.10 \\
\hline \multicolumn{2}{|l|}{ Mean } & 0.770 & \begin{tabular}{|l|}
0.790 \\
\end{tabular} & 0.990 & 1.020 & 57.96 & 58.56 & 20.44 & \begin{tabular}{|l|}
21.88 \\
\end{tabular} & 3.50 & 3.56 \\
\hline \multirow{4}{*}{$\mid \begin{array}{ll}10 \mathrm{~kg} \mathrm{/fed} \\
\text { humic acid }\end{array}$} & 0 & 0.489 & 0.495 & 0.785 & 0.794 & 55.75 & 55.96 & 18.63 & 19.31 & 2.58 & 2.66 \\
\hline & 10 & 0.861 & 0.879 & 1.034 & 1.188 & 61.55 & 62.47 & 21.63 & 22.69 & 3.86 & 3.92 \\
\hline & 20 & 0.993 & \begin{tabular}{|l|}
0.996 \\
\end{tabular} & 1.274 & 1.296 & 63.75 & 64.25 & 22.38 & \begin{tabular}{|l|}
23.19 \\
\end{tabular} & 3.97 & 4.10 \\
\hline & 30 & 1.154 & \begin{tabular}{|l|}
1.178 \\
\end{tabular} & 1.596 & 1.695 & 68.72 & 68.99 & \begin{tabular}{|l|}
22.69 \\
\end{tabular} & \begin{tabular}{|l|}
23.63 \\
\end{tabular} & 4.12 & 4.26 \\
\hline \multicolumn{2}{|l|}{\begin{tabular}{|l|} 
Mean \\
\end{tabular}} & 0.870 & 0.890 & 1.170 & 1.240 & 62.44 & 62.92 & 21.31 & 22.19 & 3.63 & 3.74 \\
\hline \multirow{4}{*}{$1 \mathrm{~g} / \mathrm{L}$} & 0 & \begin{tabular}{|l|l|}
0.469 \\
\end{tabular} & \begin{tabular}{|l|}
0.471 \\
\end{tabular} & 0.796 & 0.817 & 53.48 & 53.74 & 18.38 & \begin{tabular}{|l|}
18.63 \\
\end{tabular} & 2.36 & 2.45 \\
\hline & 10 & \begin{tabular}{|l|l|}
0.739 \\
\end{tabular} & \begin{tabular}{|l|}
0.785 \\
\end{tabular} & 0.983 & 0.998 & 54.96 & 55.62 & \begin{tabular}{|l|}
20.19 \\
\end{tabular} & \begin{tabular}{|l|}
21.06 \\
\end{tabular} & 3.24 & 3.55 \\
\hline & 20 & 0.842 & 0.896 & 1.085 & 1.125 & 56.84 & 57.25 & 20.56 & & 3.36 & 3.62 \\
\hline & 30 & 0.895 & 0.934 & 1.159 & 1.166 & 58.21 & 59.34 & 21.00 & 21.56 & 3.45 & 3.77 \\
\hline \multicolumn{2}{|l|}{ Mean } & \begin{tabular}{|l|l}
0.740 \\
\end{tabular} & \begin{tabular}{|l|}
0.770 \\
\end{tabular} & 1.010 & 1.030 & 55.87 & \begin{tabular}{|l|}
56.49 \\
\end{tabular} & 20.06 & \begin{tabular}{|l|}
20.63 \\
\end{tabular} & 3.10 & 3.35 \\
\hline \multirow{4}{*}{$2 g / L$} & 0 & 0.481 & 0.492 & 0.843 & 0.850 & 54.12 & 54.44 & \begin{tabular}{|l|}
18.56 \\
\end{tabular} & \begin{tabular}{|l|}
18.69 \\
\end{tabular} & 2.44 & 2.49 \\
\hline & 10 & 0.789 & 0.819 & 0.988 & 1.023 & 58.74 & 59.63 & 20.81 & 21.25 & 3.58 & 3.65 \\
\hline & 20 & 0.941 & 0.966 & 1.159 & 1.169 & 59.89 & 60.47 & 21.13 & \begin{tabular}{|l|}
21.69 \\
\end{tabular} & 3.76 & 3.84 \\
\hline & 30 & 0.998 & \begin{tabular}{|l|} 
\\
\end{tabular} & 1.185 & 1.197 & 61.33 & 62.76 & 21.63 & 22.13 & 3.89 & 3.97 \\
\hline \multicolumn{2}{|l|}{ Mean } & 0.800 & 0.810 & 1.040 & 1.060 & 58.52 & 59.33 & 20.56 & 20.94 & 3.42 & 3.49 \\
\hline \multicolumn{2}{|c|}{ L.S.D. 5\% Methods } & 0.039 & 0.044 & 0.040 & 0.035 & 1.92 & 1.32 & ns & ns & 0.43 & 0.55 \\
\hline \multicolumn{2}{|l|}{ L.S.D. Rate N } & 0.047 & 0.040 & 0.056 & 0.031 & 1.32 & 0.91 & 5.50 & 5.50 & ns & $\mathrm{ns}$ \\
\hline \multicolumn{2}{|c|}{ Interaction R XM } & t* & ns & ** & ** & ns & t & ns & ns & ns & ns \\
\hline
\end{tabular}


Effect of interaction between methods of humic acid and mineral $\mathrm{N}$ fertilizer was significant in its effect on seeds yield (ton/fed) in the first season and pods yield (ton/fed) in both seasons, while the weight of 100 seeds ( $\mathrm{g}$ ) was significant in the second season. Effect of interaction between methods system of humic acid and mineral $\mathrm{N}$ - fertilizer was no significant as affect on protein (\%) and chlorophyll content in plant. The relative increase of mean values were 12.99 and $12.66,18.18$ and $21.57,7.73$ and $7.45,4.26$ and 1.42, 3.71 and $5.06 \%$ for seed yield (ton/fed), Pods yield (ton/fed), weight of 100 seeds $(\mathrm{g})$ protein $(\%)$ and chlorophyll $(\mathrm{a}+\mathrm{b}) \mathrm{mg} / \mathrm{g}$ f.w, respectively in the first and second seasons as soil treated with application of $10 \mathrm{~kg}$ humic acid/ fed compared with applied $5 \mathrm{~kg}$ humic acid. Also, the relative increase of mean values were 8.11 and 5.19, 2.97 and 2.91, 4.74 and 5.03, 2.49 and 1.50, 10.32 and $4.18 \%$, respectively in the first and second seasons for soil treated with foliar application at rate of $2 \mathrm{~g}$ humic acid/ $\mathrm{L}$ method compared with foliar application at rate of $1 \mathrm{~g}$ humic acid/L. The relative increases of mean values were 6.49 and $6.33 \%$ seed yield (ton/fed); 5.37 and $8.13 \%$ for pod yield (ton/fed); 5.25 and $4.89 \%$ for weight of 100 seed (g); 2.78 and $6.01 \%$ for protein (\%) content in seeds and 9.36 and $6.37 \%$ for chlorophyll content in plant in the first and second seasons, respectively as affected by humic acid application method compared with foliar application method system. Comparison between the two methods of application humic acid and its impact on characters of faba bean, it was found that the addition of humic acid application was better than foliar application. These results are in agreement with El-Bassiony et al. (2010) who showed that foliar application by humic acid (at 1,2 or $3 \mathrm{~g} / \mathrm{L}$ ) significantly affected on all the vegetative growth parameters, i.e. plant height, number of leaves and branches as well as fresh and dry weight of whole snap bean plants (Phaseolus vulgaris, L.) cv. Paulesta grown under sandy soil conditions comparing with control plants. Maral (2012) indicated that interaction effect of humic acid and nitrogen management on seeds yield, straw yield and harvest index showed significant differences at $5 \%$ probability level. On the other hand, the humic acid application at rate of $10 \mathrm{~kg} / \mathrm{fed}$ combined with $30 \mathrm{~kg} \mathrm{~N} / \mathrm{fed}$ gave the highest values of seeds yield/fed, pods yield /fed weight of 100 seeds , protein (\%) and chlorophyll content in faba bean plants compared with other treatments. Hanafy et al. (2010) indicated that addition of humic acid, significantly increased chlorophyll a and total chlorophylls. The beneficial effect of humic acid on plant growth could be referred to its acting as a source of plant growth hormones. Humic acids are considered as an important source of organic matter and their effects on yield and its components could be through their enhancing effect on increase soil moisture holding capacity, improve soil texture as well as promote the uptake of nutrients leading to stimulation of plant growth (higher biomass production) and consequently on total pods yield and its components (Zhang et al., 2003).

Macronutrients concentration in seeds of faba bean:

Effect of methods of humic acid systems addition on N, P and $\mathrm{K}$ concentration in seeds of faba bean plants are presented in Table 4. Concerning the effect of humic acid application on N, P and K concentration in seeds were increased with increasing rates of humic $(10 \mathrm{~kg} / \mathrm{fed})$ and 
Dalia A. Sayed et al.

mineral $\mathrm{N}$ fertilizer (30 $\mathrm{kg} \mathrm{N} / \mathrm{fed}$ ). The effect of humic acid application methods (application or foliar) was significantly increase for $\mathrm{N}$ and $\mathrm{K}$ in both seasons, while the $\mathrm{K}$ concentration was no significant in the first season.

Table 4. Macronutrients concentration in seeds faba bean plant

\begin{tabular}{|c|c|c|c|c|c|c|c|}
\hline \multirow[t]{2}{*}{ Treatments } & \multirow{2}{*}{$\begin{array}{c}\text { Rates of } \\
\mathrm{N} \\
\mathrm{kg} \mathrm{fed}^{-1}\end{array}$} & \multicolumn{2}{|c|}{$\begin{array}{l}N \\
(\%)\end{array}$} & \multicolumn{2}{|c|}{$\begin{array}{l}P \\
(\%)\end{array}$} & \multicolumn{2}{|c|}{$\begin{array}{l}K \\
(\%)\end{array}$} \\
\hline & & $1^{\text {st }}$ & $2^{\text {nd }}$ & $1^{\text {st }}$ & $2^{\text {nd }}$ & $1^{\text {st }}$ & $2^{\text {nd }}$ \\
\hline \multirow{4}{*}{$\begin{array}{l}5 \mathrm{~kg} \text { /fed humic } \\
\text { acid }\end{array}$} & 0 & 2.95 & 3.04 & 0.38 & 0.39 & 2.36 & 2.38 \\
\hline & 10 & 3.33 & 3.58 & 0.45 & 0.46 & 2.49 & 2.51 \\
\hline & 20 & 3.38 & 3.66 & 0.49 & 0.51 & 2.52 & 2.55 \\
\hline & 30 & 3.43 & 3.71 & 0.55 & 0.55 & 2.56 & 2.59 \\
\hline \multicolumn{2}{|l|}{ Mean } & 3.27 & 3.50 & 0.47 & 0.48 & 2.48 & 2.51 \\
\hline \multirow{4}{*}{$\begin{array}{l}10 \mathrm{~kg} / \mathrm{fed} \text { humic } \\
\text { acid }\end{array}$} & 0 & 2.98 & 3.09 & 0.40 & 0.41 & 2.39 & 2.41 \\
\hline & 10 & 3.46 & 3.63 & 0.47 & 0.50 & 2.54 & 2.58 \\
\hline & 20 & 3.58 & 3.71 & 0.53 & 0.58 & 2.59 & 2.63 \\
\hline & 30 & 3.63 & 3.78 & 0.57 & 0.62 & 2.64 & 2.66 \\
\hline \multicolumn{2}{|l|}{\begin{tabular}{|l} 
Mean \\
\end{tabular}} & 3.41 & 3.55 & 0.49 & 0.53 & 2.54 & 2.57 \\
\hline \multirow{4}{*}{$1 \mathrm{~g} / \mathrm{L}$} & 0 & 2.94 & 2.98 & 0.35 & 0.37 & 2.36 & 2.38 \\
\hline & 10 & 3.23 & 3.37 & 0.39 & 0.42 & 2.41 & 2.42 \\
\hline & 20 & 3.29 & 3.39 & 0.42 & 0.45 & 2.45 & 2.47 \\
\hline & 30 & 3.36 & 3.45 & 0.46 & 0.49 & 2.49 & 2.51 \\
\hline \multicolumn{2}{|l|}{ Mean } & 3.21 & 3.30 & 0.41 & 0.43 & 2.43 & 2.45 \\
\hline \multirow{4}{*}{$2 g / L$} & 0 & 2.97 & 2.99 & 0.39 & 0.41 & 2.39 & 2.43 \\
\hline & 10 & 3.33 & 3.40 & 0.43 & 0.48 & 2.44 & 2.48 \\
\hline & 20 & 3.38 & 3.47 & 0.47 & 0.53 & 2.48 & 2.52 \\
\hline & 30 & 3.46 & 3.54 & 0.52 & 0.58 & 2.53 & 2.57 \\
\hline \multicolumn{2}{|l|}{\begin{tabular}{|l|} 
Mean \\
\end{tabular}} & 3.29 & 3.35 & 0.45 & 0.50 & 2.46 & 2.50 \\
\hline \multicolumn{2}{|c|}{ L.S.D. $5 \%$ methods of humic } & 0.35 & 0.22 & 0.021 & 0.027 & ns & 0.016 \\
\hline \multicolumn{2}{|l|}{ L.S.D. Rate N } & ns & ns & 0.019 & 0.014 & ns & 0.014 \\
\hline \multicolumn{2}{|l|}{ Interaction $\mathrm{R} \times \mathrm{H}$} & ns & ns & ns & ns & ns & ** \\
\hline
\end{tabular}

As regards to the foliar application of humic acid system, was increase of $\mathrm{N}, \mathrm{P}$ and $\mathrm{K}$ concentration in seeds of faba bean plants with increasing rates (humic acid $2 \mathrm{~g} / \mathrm{L}$ and $30 \mathrm{~kg} \mathrm{~N} / \mathrm{fed}$ ). On the other hand, the interaction between humic acid methods system and different rates of mineral $\mathrm{N}$ fertilizer no significantly effect on $\mathrm{N}$ and $\mathrm{P}$ concentration in seeds except $\mathrm{K}$ was significant in the second season. The relative increases of mean values were 2.77 and $6.02 \%$ for $\mathrm{N} ; 11.63$ and $8.60 \%$ for $\mathrm{P}$ and 2.66 and 2.63 for $\mathrm{K}$ concentrations in seeds for the first and second seasons as affected by humic acid application compared with humic acid foliar application system. These results are in agreement with El-Ghamry et al.(2009) who found significant increases in N, P and $\mathrm{K}$ content in seed and straw of faba bean plants as response to humic acid added (at 1000, 2000 or 3000 ppm). Hanafy et al (2010) reported that humic acid application was significantly increased $\mathrm{N}, \mathrm{P}$ and $\mathrm{K}$ content in snap bean.

Micronutrients concentration in seeds of faba bean plants.

Data presented in Table 5 show that the effect of humic acid application methods on Fe, $\mathrm{Mn}$ and $\mathrm{Zn}$ concentration in seeds was significant increase 
with increasing rates. On the other hand, the effect of different rates of mineral $\mathrm{N}$ on $\mathrm{Fe}, \mathrm{Mn}$ and $\mathrm{Zn}$ were significant increase with increasing rates. The interaction between humic acid methods system application and different rates of mineral $\mathrm{N}$ were significantly increase for $\mathrm{Fe}$ in both seasons but no significant for $\mathrm{Mn}$ and $\mathrm{Zn}$ concentration in seeds of faba bean plants. The relative increases of mean values were 10.69 and $11.55 \%$ for $\mathrm{Fe} ; 8.48$ and $9.85 \%$ for $\mathrm{Mn}$ and 6.71 and $10.60 \%$ for $\mathrm{Zn}$ concentration in seeds of faba bean plants in the first and second seasons, respectively, as affected by humic acid application system compared with humic acid foliar method.

Table 5. Micronutrients concentration in the seeds of faba bean plant

\begin{tabular}{|c|c|c|c|c|c|c|c|}
\hline \multirow[t]{2}{*}{ Treatments } & \multirow{2}{*}{$\begin{array}{c}\text { Rates of } \\
\mathrm{N} \\
\mathrm{kg} \mathrm{fed}^{-1}\end{array}$} & \multicolumn{2}{|c|}{$\begin{array}{c}\text { Fe } \\
\left(\mathrm{mgkg}^{-1}\right)\end{array}$} & \multicolumn{2}{|c|}{$\begin{array}{c}\text { Mn } \\
\left(\mathrm{mgkg}^{-1}\right)\end{array}$} & \multicolumn{2}{|c|}{$\begin{array}{c}\mathrm{Zn} \\
\left(\mathrm{mgkg}^{-1}\right)\end{array}$} \\
\hline & & $1^{\text {st }}$ & $2^{\text {nd }}$ & $1^{\mathrm{st}}$ & $2^{\text {nd }}$ & $1^{\mathrm{st}}$ & $2^{\text {nd }}$ \\
\hline \multirow{4}{*}{$\begin{array}{l}5 \mathrm{~kg} / \mathrm{fed} \text { humic } \\
\text { acid }\end{array}$} & 0 & 75.63 & 76.19 & 46.98 & 47.05 & 17.16 & 18.67 \\
\hline & 10 & 86.14 & 88.52 & 49.62 & 50.35 & 20.68 & 22.56 \\
\hline & 20 & 89.29 & 90.36 & 53.14 & 54.69 & 22.53 & 24.79 \\
\hline & 30 & 95.47 & 96.10 & 55.37 & 58.41 & 22.98 & 26.33 \\
\hline \multicolumn{2}{|l|}{\begin{tabular}{|l|} 
Mean \\
\end{tabular}} & 86.63 & 87.79 & 51.28 & 52.63 & 20.84 & 23.09 \\
\hline \multirow{4}{*}{$\begin{array}{l}10 \mathrm{~kg} / \mathrm{fed} \text { humic } \\
\text { acid }\end{array}$} & 0 & 76.98 & 79.84 & 47.34 & 49.85 & 19.85 & 20.47 \\
\hline & 10 & 92.17 & 93.55 & 55.47 & 57.63 & 24.36 & 26.88 \\
\hline & 20 & 98.34 & 108.36 & 59.32 & 62.14 & 28.59 & 30.48 \\
\hline & 30 & 114.36 & 119.45 & 62.48 & 67.35 & 30.14 & 34.29 \\
\hline \multicolumn{2}{|l|}{ Mean } & 95.46 & 100.30 & 56.15 & 59.24 & 25.74 & 28.03 \\
\hline \multirow{4}{*}{$1 \mathrm{~g} / \mathrm{L}$} & 0 & 69.88 & 70.52 & 44.62 & 45.19 & 16.48 & 17.17 \\
\hline & 10 & 77.89 & 79.64 & 48.37 & 49.56 & 19.75 & 20.66 \\
\hline & 20 & 82.14 & 84.23 & 50.44 & 53.17 & 21.37 & 22.43 \\
\hline & 30 & 88.96 & 89.67 & 52.95 & 54.33 & 22.00 & 24.61 \\
\hline \multicolumn{2}{|l|}{ Mean } & 79.72 & 81.02 & 49.10 & 50.56 & 19.90 & 21.22 \\
\hline \multirow{4}{*}{$2 g / L$} & 0 & 72.19 & 73.55 & 45.68 & 46.85 & 18.74 & 20.08 \\
\hline & 10 & 85.36 & 89.22 & 47.52 & 47.67 & 21.66 & 22.95 \\
\hline & 20 & 88.75 & 91.43 & 52.19 & 53.22 & 25.84 & 26.74 \\
\hline & 30 & 92.85 & 96.17 & 54.32 & 57.39 & 28.77 & 30.22 \\
\hline \multicolumn{2}{|l|}{ Mean } & 84.79 & 87.59 & 49.93 & 51.28 & 23.75 & 25.00 \\
\hline \multicolumn{2}{|c|}{ L.S.D. $5 \%$ methods } & 2.01 & 1.87 & 2.39 & 1.92 & 1.78 & 2.59 \\
\hline \multicolumn{2}{|l|}{ L.S.D. Rate N } & 2.42 & 3.24 & 1.73 & 1.93 & 2.63 & 3.89 \\
\hline \multicolumn{2}{|l|}{ Interaction R X M } & $\star \star$ & ** & ns & $\mathrm{ns}$ & $\mathrm{ns}$ & $\mathrm{ns}$ \\
\hline
\end{tabular}

These results are in agreement with Hanafy et al (2010) who reported that humic acid application was significantly increased $\mathrm{Fe}, \mathrm{Mn}$ and $\mathrm{Zn}$ content in snap bean. Shafeek et al. (2013) found that humic acid application was significant increase in the accumulation of $\mathrm{Fe}, \mathrm{Mn}$ and $\mathrm{Zn}$ in tissues of plants. Shehata et al. (2012) indicated that the spraying with humic acid $(1.5 \mathrm{~g} / \mathrm{L})$ led to increase of nutrients accumulation in plants.

Effect of methods application of humic acid on Available nutrients in soil.

Available macronutrients in soil.

Data presented in Table 6 show that the soil application of humic acid with $10 \mathrm{~kg} / \mathrm{fed}$ and $30 \mathrm{~kg} \mathrm{~N}$ fed led to the highest available $\mathrm{N}, \mathrm{P}$ and $\mathrm{K}$ content 
Dalia A. Sayed et al.

in soil after faba bean harvest compared with the other treatments. Also, the humic acid foliar application with $2 \mathrm{~g} / \mathrm{L}$ combined with $30 \mathrm{~kg} \mathrm{~N} / \mathrm{fed}$ gave higher available $\mathrm{N}, \mathrm{P}$ and $\mathrm{K}$ content in soil than foliar with humic acid alone. The effect of methods of application for humic acid on $\mathrm{N}$ and $\mathrm{K}$ contents in soil were significantly increased in both seasons, expect $P$ in the first season was no significant. On the other hand, the different rates of mineral nitrogen were significant for $\mathrm{N}$ in first season and $\mathrm{K}$ content in both seasons, while $\mathrm{P}$ content in soil was no significant in first season. The interaction between method application of humic acid system and different rates of mineral $\mathrm{N}$ fertilizer on N, P and $\mathrm{K}$ content in soil were no significant affect. The relative increases of mean values were 4.02 and $4.16 \%$ for $\mathrm{N} ; 5.94$ and $6.80 \%$ for $\mathrm{P}$ and 4.16 and $2.85 \%$ for $\mathrm{K}$ content in soil in the first and second seasons, respectively as affected by humic acid soil application compared with foliar application method system. These results are in agreement with Mohammad et al (2014) who found that the humic acid substances on soil was the active constituent of organic humus and improve soil biologically, soil organisms and increase nutrients.

Table 6. Available macronutrients content in soil as affected by different methods of application the humic acid

\begin{tabular}{|c|c|c|c|c|c|c|c|}
\hline \multirow[t]{2}{*}{ Treatments } & \multirow{2}{*}{$\begin{array}{c}\text { Rates of } \\
\mathrm{N} \\
\mathrm{kg} \mathrm{fed}^{-1}\end{array}$} & \multicolumn{2}{|c|}{$\begin{array}{c}\mathbf{N} \\
\left(\mathrm{mgkg}^{-1}\right)\end{array}$} & \multicolumn{2}{|c|}{$\begin{array}{c}\mathbf{P} \\
\left(\mathrm{mgkg}^{-1}\right)\end{array}$} & \multicolumn{2}{|c|}{$\begin{array}{c}\mathrm{K} \\
\left(\mathrm{mgkg}^{-1}\right)\end{array}$} \\
\hline & & $1^{\mathrm{st}}$ & $2^{\text {nd }}$ & $1^{s t}$ & $2^{\text {nd }}$ & $1^{\mathrm{st}}$ & $2^{\text {nd }}$ \\
\hline \multirow{4}{*}{$\begin{array}{l}5 \mathrm{~kg} / \mathrm{fed} \text { humic } \\
\text { acid }\end{array}$} & 0 & 34.82 & 34.89 & 3.67 & 3.75 & 193.00 & 195.00 \\
\hline & 10 & 36.59 & 36.99 & 3.89 & 3.95 & 198.00 & 203.00 \\
\hline & 20 & 37.25 & 37.72 & 3.94 & 3.98 & 204.00 & 208.00 \\
\hline & 30 & 37.86 & 37.93 & 3.99 & 4.03 & 209.00 & 213.00 \\
\hline \multicolumn{2}{|l|}{ Mean } & 36.63 & 36.88 & 3.87 & 3.93 & 201.00 & 204.75 \\
\hline \multirow{4}{*}{$\begin{array}{l}10 \mathrm{~kg} / \mathrm{fed} \text { humic } \\
\text { acid }\end{array}$} & 0 & 34.98 & 35.00 & 3.72 & 3.73 & 196.00 & 199.00 \\
\hline & 10 & 38.55 & 38.96 & 4.12 & 4.25 & 203.00 & 207.00 \\
\hline & 20 & 39.42 & 39.76 & 4.36 & 4.41 & 208.00 & 214.00 \\
\hline & 30 & 39.86 & 40.39 & 4.39 & 4.56 & 216.00 & 219.00 \\
\hline \multicolumn{2}{|l|}{\begin{tabular}{|l|} 
Mean \\
\end{tabular}} & 38.20 & 38.53 & 4.15 & 4.24 & 205.75 & 209.75 \\
\hline \multirow{4}{*}{$1 \mathrm{~g} / \mathrm{L}$} & 0 & 34.12 & 34.22 & 3.62 & 3.66 & 185.00 & 189.00 \\
\hline & 10 & 35.61 & 35.78 & 3.67 & 3.72 & 189.00 & 197.00 \\
\hline & 20 & 35.88 & 36.13 & 3.73 & 3.76 & 194.00 & 198.00 \\
\hline & 30 & 36.10 & 36.55 & 3.79 & 3.83 & 198.00 & 205.00 \\
\hline \multicolumn{2}{|l|}{ Mean } & 35.43 & 35.67 & 3.70 & 3.74 & 191.50 & 197.25 \\
\hline \multirow{4}{*}{$2 g / L$} & 0 & 34.55 & 34.68 & 3.70 & 3.72 & 190.00 & 198.00 \\
\hline & 10 & 35.87 & 36.10 & 3.88 & 3.93 & 197.00 & 204.00 \\
\hline & 20 & 37.62 & 37.88 & 3.92 & 3.95 & 203.00 & 209.00 \\
\hline & 30 & 37.99 & 38.24 & 3.98 & 4.05 & 206.00 & 212.00 \\
\hline \multicolumn{2}{|l|}{ Mean } & 36.51 & 36.73 & 3.87 & 3.91 & 199.00 & 205.75 \\
\hline \multicolumn{2}{|l|}{ L.S.D. 5\% Methods } & 1.25 & 1.23 & ns & 0.20 & 3.27 & 1.92 \\
\hline L.S.D. Rate N & & 1.04 & ns & $\mathrm{ns}$ & 0.28 & 2.92 & 1.74 \\
\hline \multicolumn{2}{|l|}{ Interaction R XM } & ns & ns & ns & ns & ns & $\mathrm{ns}$ \\
\hline
\end{tabular}

Available micronutrients in soil.

Effect of methods system application or foliar of humic acid on available

$\mathrm{Fe}, \mathrm{Mn}$ and $\mathrm{Zn}$ content in soil after faba bean harvest was positive effect. 
Results were represented in Table 7. Methods of humic acid application and different rates of mineral $\mathrm{N}$ fertilizer were significant effect on $\mathrm{Fe}$ in the first season and $\mathrm{Mn}$ and $\mathrm{Zn}$ content of soil in both seasons. The interaction between methods of humic acid application and different rates of mineral $\mathrm{N}$ fertilizer on Fe was significant in the first season and $\mathrm{Mn}$ in both seasons, while $\mathrm{Zn}$ was no significant in both seasons. The positive effect of humic substances in increasing the availability of micronutrients may be due its priming effect to increase water soluble amounts of micronutrients after addition of humic substances, which led to chelating and subsequent release of micronutrients (Baris and Ali, 2013).

Table 7. Available micronutrients content in soil as affected by different methods application of humic acid

\begin{tabular}{|c|c|c|c|c|c|c|c|}
\hline \multirow[t]{2}{*}{ Treatments } & \multirow{2}{*}{$\begin{array}{c}\text { Rates of } \\
N \\
\text { kg fed }^{-1}\end{array}$} & \multicolumn{2}{|c|}{$\begin{array}{c}\mathrm{Fe} \\
\left(\mathrm{mgkg}^{-1}\right)\end{array}$} & \multicolumn{2}{|c|}{$\begin{array}{c}\text { Mn } \\
\left(\mathrm{mgkg}^{-1}\right)\end{array}$} & \multicolumn{2}{|c|}{$\begin{array}{c}\mathrm{Zn} \\
\left(\mathrm{mgkg}^{-1}\right)\end{array}$} \\
\hline & & $1^{\text {st }}$ & $2^{\text {nd }}$ & $1^{\text {st }}$ & $2^{\text {nd }}$ & $1^{\text {st }}$ & $2^{\text {nd }}$ \\
\hline \multirow{4}{*}{$5 \mathrm{~kg} / \mathrm{fed}$ humic acid } & 0 & 1.96 & 1.98 & 1.43 & 1.45 & 0.59 & 0.62 \\
\hline & 10 & 2.07 & 2.12 & 1.59 & 1.62 & 0.63 & 0.67 \\
\hline & 20 & 2.15 & 2.18 & 1.66 & 1.68 & 0.68 & 0.75 \\
\hline & 30 & 2.19 & 2.24 & 1.72 & 1.75 & 0.74 & 0.79 \\
\hline \multicolumn{2}{|l|}{ Mean } & 2.09 & 2.13 & 1.60 & 1.63 & 0.66 & 0.71 \\
\hline \multirow{4}{*}{$10 \mathrm{~kg} / \mathrm{fed}$ humic acid } & 0 & 1.99 & 2.01 & 1.44 & 1.49 & 0.60 & 0.63 \\
\hline & 10 & 2.09 & 2.14 & 1.68 & 1.75 & 0.68 & 0.75 \\
\hline & 20 & 2.18 & 2.23 & 1.88 & 1.93 & 0.73 & 0.78 \\
\hline & 30 & 2.23 & 2.28 & 1.93 & 1.98 & 0.79 & 0.86 \\
\hline \multicolumn{2}{|l|}{ Mean } & 2.12 & 2.17 & 1.73 & 1.79 & 0.70 & 0.76 \\
\hline \multirow{4}{*}{$1 \mathrm{~g} / \mathrm{L}$} & 0 & 1.92 & 1.95 & 1.37 & 1.38 & 0.52 & 0.53 \\
\hline & 10 & 1.95 & 1.98 & 1.42 & 1.43 & 0.58 & 0.59 \\
\hline & 20 & 1.98 & 2.00 & 1.47 & 1.48 & 0.60 & 0.63 \\
\hline & 30 & 2.02 & 2.07 & 1.49 & 1.53 & 0.67 & 0.69 \\
\hline \multicolumn{2}{|l|}{ Mean } & 1.97 & 2.00 & 1.44 & 1.46 & 0.59 & 0.61 \\
\hline \multirow{4}{*}{$2 g / L$} & 0 & 1.94 & 1.98 & 1.39 & 1.40 & 0.54 & 0.56 \\
\hline & 10 & 1.97 & 1.99 & 1.46 & 1.50 & 0.65 & 0.63 \\
\hline & 20 & 2.05 & 2.09 & 1.52 & 1.56 & 0.70 & 0.66 \\
\hline & 30 & 2.09 & 2.13 & 1.66 & 1.69 & 0.72 & 0.77 \\
\hline \multicolumn{2}{|l|}{ Mean } & 2.01 & 2.05 & 1.51 & 1.54 & 0.65 & 0.66 \\
\hline \multicolumn{2}{|l|}{ L.S.D. 5\% humic } & 0.024 & ns & 0.015 & 0.024 & 0.030 & 0.023 \\
\hline \multirow{2}{*}{\multicolumn{2}{|c|}{ L.S.D. Rate N }} & 0.025 & ns & 0.011 & 0.024 & 0.024 & 0.006 \\
\hline & Interaction $\mathrm{R}$ XH & ** & ns & ** & ** & ns & $\mathrm{ns}$ \\
\hline
\end{tabular}

It was also reported that the addition of humic acid to a soil increased the available of $\mathrm{Fe}, \mathrm{Mn}$ and $\mathrm{Zn}$ than foliar humic acid. The corresponding relative increases of mean values were 5.78 and $6.17 \%$ for $\mathrm{Fe}, 12.88$ and $14.00 \%$ for $\mathrm{Mn}$ and 9.68 and $15.75 \%$ for $\mathrm{Zn}$ available in soil in the first and second seasons, respectively, as affected by soil application of humic acid method compared with foliar application of humic acid method system. Differently 
this result may relate to increasing microorganism activity in soil. The ability of humic acid to complex soil elements makes nutrients more available to microbes. Nardi et al. (2005) found that the humic acid substances are recognized as a key component of soil fertility properties, since they control chemical and biological properties of rhizosphere. Sharif et al., (2002) found that the indirect influences of humic acids on plant growth because they can improve soil properties such as aggregation, aeration, permeability, water holding capacity, hormonal activity, microbial growth, organic matter mineralization and solubilisation and availability of microelements ( $\mathrm{Fe}, \mathrm{Zn}$ and $\mathrm{Mn})$ elements .

\section{CONCLUSION}

These results show that addition methods of soil application and foliar application humic acid were effective for plant growth. As a conclusion, added of 5 and $10 \mathrm{~kg} / \mathrm{fed}$ rate of humic acid and $1 \mathrm{~g} / \mathrm{L}$ and $2 \mathrm{~g} / \mathrm{L}$ were found more effective doses with related to availability of macro-micronutrients in soil. However, applications of soil application and foliar of humic acid methods at relationship soil properties with faba bean growth and nutrient uptake of plant were found more effectively than foliar application.

\section{REFERENCE}

Abdel-Razzak, H.S. and G.A. El-Sharkawy (2013). Effect of bio-fertilizer and humic acid applications on growth,yield, quality and storability of two garlic cultivars. Asian J. of Crop Sci., 5(1): 48-74.

Adeyeye, A. S., A.O. Togun, W.B. Akanbi, I. O. Adepoju and D.O. Ibirinde (2014). Effect of maize stover compost and nitrogen fertilizer rates on growth and yield of soybean (Glycine Max) variety in South West Nigeria. J .of. Agric. and Veterinary Sci.7 (1): 68 - 74.

Ahmed, M. K. A. , M. S. Zeidan and M. F. El-Karamay (2003). Effect of foliar nutrition with potassium sources on growth yield and quality of faba bean (Vicia faba L.). Egypt . J. Agron. 25: 53- 58.

Ahmed, M. Y. and M. I.Yassin (2013). Effect of fertilizers (Urea, Farmyard and Chicken manure) on growth and yield of Rhods grass (Chloris Gayana L. Knuth.). Universal J. of Plant Sci. 1 (3): 85- 90.

Antoun, L.W., M.Z. Sahar and H.R. Hanaa, (2010). Influence of compost, Nmineral and humic acid on yield and chemical composition of wheat plants. J. Soil Sci. and Agric. Engi. Mansoura Univ., 1(11): 1131-1143.

Atere, C. T. and A. Olayinka, (2012). Effect of organo - mineral fertilizer on soil chemical properties, growth yield of soybean. Afric. J. of Agric. Res. 7 (37): 5208- 5216.

Baris, B. A. and V. K . Ali (2013). Detrmination of effects on solid and liquid humic acid substances to plant growth and soil micronutrient availability. J of Food. Agric. and Envi. 11 (2): $1182-1186$.

Bloom PR (2000) Soil pH and pH buffering. In: Hand book of Soil Science. Sumner ME (ed.) CRC press. USA pp. 333-352 
Chapman, H.D. and P.F. Pratt, (1961). "Methods of Analysis for Soils, Plants and Water". Agric. Publ. Univ., of California, Riverside.

Cottenie, A., M. Verloo, L. Kikens, G. Velghe and R. Camerlynck, (1982). "Analytical Problems and Method in Chemical Plant and Soil Analysis". Hand book Ed. A. Cottenie, Gent, Belgium.

Darur, I, H. Sepetoglu, Kh. B. Marwat, G. Hassan and I. Aamad Khan (2008).Effect of different levels of nitrogen on dry matter and grain yield of faba bean (Vicia faba L.). Pak. J. Bot. 40 (6): 2453- 2459.

El-Bassiony, A. M.; Z. F.Fawzy, M. M. H. Abd El-Baky and A. R. Mahmoud (2010). Response of snap bean plants to mineral fertilizers and humic acid application. Res. J. Agric. Biol. Sci., 6(2):169-175.

El-Ghamry, A.M., K.M. Abd El-Hai and K.M. Ghoneem. (2009). Amino and humic acids promote growth, yield, and disease resistance of faba bean cultivated in clayey soil. Austr. J. Basic \& Appl. Sci. 3:731-739.

El-Kotb, H. M. A. (2013). Combination effects of tillage systems and organic manure on some physio-chemical properties of calcareous soil and faba bean productivity. New York Sci. J. 3- 6 (2): 193 -202

Hamid, R. B., A. Ebrahim, and M. Maral (2011). The effects of bio, mineral nitrogen fertilization and foliar Zinc spraying on yield and yield components of faba bean. World Applied Sic. J. 13 (6): 1409- 1414.

Hanafy, A. A. , M. R. Nesiem, A. M. Hewedy and H. El-S. Sallam (2010). Effect of some simulative compounds on growth, yield and chemical composition of snap bean plants grown under calcareous soil conditions. J. of American Sci. 6 (10): 552- 569.

Hartwigson, J.A. and M.R. Evans, (2000). Humic acid seed and substrate treatments promote seedling root development. HortScience, 35(7):1231-1233.

Hymowitz, T.F., P. Collins and W.M. Walker (1972). Relationship between the content of oil, protein and sugar in soybean seed. Agron. J., 64: 613616.

Jackson, M.L., (1973). "Soil Chemical Analysis". Prentice Hall India.

Kaya, M.; M. Atak ; K. Khawar; M. Cemalettin; Y. Ciftci and S. Özcan, (2005). Effect of pre- sowing seed treatment with zinc and foliar spray of humic acids on yield of common bean (Phaseolus vulgaris, L.). International J. Agric. Biol., 7(6):875-878.

Kocon, Ë. A., (2010). The effect of foliar or soil top-dressing of urea on some physiological processes and seed yield of faba bean.Polish Journal of Agronomy, (3), 15-19.

Maral, M. (2012). Effects of humic aicd foliar spraying and nitrogen fertilizer management on yield of peanut (Arachis hypogaea L.) in Iran. J. of Agric. And Biol. Sci. 7 (4): 289- 293.

Mauromicale, G., M. G. L. Angela and A. L. Monaco (2011). The effect of organic supplementation of solarized soil on the quality of tomato. Scientia Hort., 129 (2): 189-196.

Mohamed, A., A. Bakry, Y. R. A. Soliman and S. A. M. Moussa (2009). Importance of micronutrients, organic manure and bio-fertilizer for improving maize yield and its components grown in desert sandy soil. Res. J. Agric. \& Bio. Sci., 5 (1): 16-23. 
Mohammad, F. , M. Hossein, N. Mohsen, S. Alizeza, A. Mohammad, A. Shilla and R. Khashayar, (2014). Influence of humic acid on increase yield of plants and soil properties. Intr. J. of Farming and Allied Sci. 3 (3): 339 341.

Mohammad M.A., M.A. Sabah and A.M. Rehab (2011) Inflance of potassium sulfate on faba bean yield and quality. Australian Journal of Basic and Applied Sciences, 5(3): 87-95.

Nardi, S., M. Tosoni, , D. Pizzeghello, M. R. Provenzano, and A.Cilenti (2005). Chemical characteristics and biological activity of organic substances extracted from soils by root exudates. Soil Sci. Soc. Am. J. (69):2012-2019.

Page, A.L., R.H. Miller and D.R. Keeney, (1982). "Methods of Chemical Analysis". Part 2: Chemical and microbiological properties (Second Edition). American Society of Agronomy, Inc. and Sci. Soc. of America, Inc. Publishers, Madison, Wisconsin U.S.A.

Prusiński, J. (2007). Content and balance of nitrogen in faba bean fertilized with ammonium nitrate and fed additionally with urea Electronic Journal of Polish Agricultural Universities, 10, (4): 258- $266 .$.

Rajpar, I. M. B. Bhatti, Z. U. Hassan, A.N. Shah and S.D. Tunio (2011). Humic acid improves growth, yield and oil content of Brassica comperstris L.Pak. J. Agri. Agri. Engg. Sci. 27(2): 125-133.

Richards, L.A. (editor). (1954) "Diagnosis and Improvement of Saline and Alkaline Soils, "USDA, Handbook 60.

Salman, S.D.A. , A.M.R. Abdel-Mawgoud and M.A. El-Nemr (2005). Furit yield and quality of watermelon as affected by hybrids and humic acid application. J. of appl. Sci. Res. 1 (1): 51: 58.

Shafeek, M.R., Y. I. Helmy, N. M.Omer, and F. A. Rizk (2013). Effect of foliar fertilizer with nutritional compound and humic acid on growth and yield of broad bean plants under sandy soil conditions. J. of Appl. Sci. Res. 9 (6): 3674- 3680.

Sharif, M., R. A. Khattak, and M. S. Sarir (2002). Effect of different levels of lignitic coal derived humic acid on growth of maize plants. Commun. Soil Sci. Plant Anal. 33: 3567-3580.

Shehata, S.A., Y.M. Ahmed, T.Y. Emam and M.A. Azoz (2012). Influence of some organic and inorganic fertilizers on vegetative growth, yield and yield components of cucumber plants. Research J. of Agric. and Biolo Scie, 8(2): 108-114.

Sndecore, G.W. and W. G. Cochran , (1990) " Statistical Methods $7^{\text {th }}$ ed . IOWA, state Univ. U.S.A.

SoltanPoure. N. (1985). "Use of ammonium bicarbonate- DTPA soil test to evaluate elemental availability and toxicity. "Soil Sci. Plant Anal., 16 (3): $323-338$.

Soltan Pour, N. and A.P. Schwab (1977). "Anew soil test for simultaneous extraction of macro and micronutrients in alkaline soils." Commun. Soil Sci. plant Anal., 3: 195.

Witham, F.H., D.F. Blaydes and P.M. Devin, (1971). "Experiments in plant physiology". Van Nosland Reihold. Co. New York, 55-58. 
Zhang, X., E. H. Ervin and R. E. Schmidt, (2003). Physiological effect of liquid applications of a seaweed extracts and humic acid on creeping. J. Amer. Soc. Hort. Sci., 128(4):492-496.

تاثير طرق اضافة حمض الهيوميك المتحد مـع التسميد النيتروجينى على خصوبة

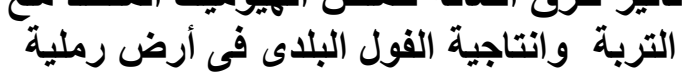

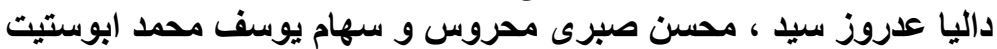

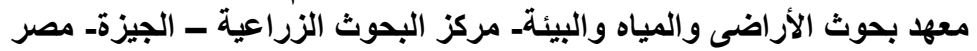

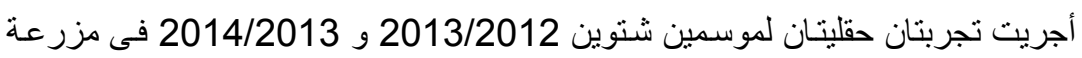

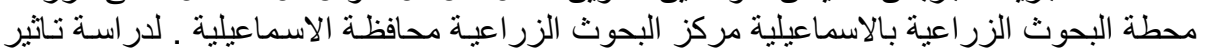

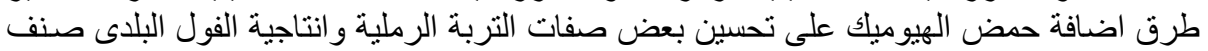

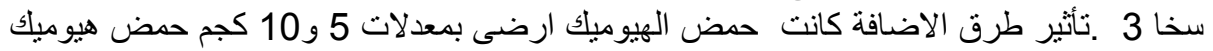

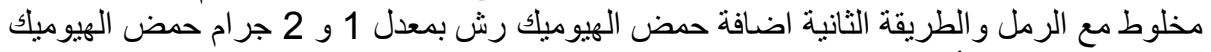

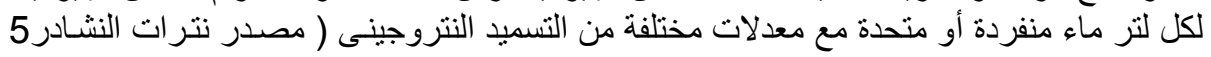
. \% 33. وقد اوضحت النتائج ان:

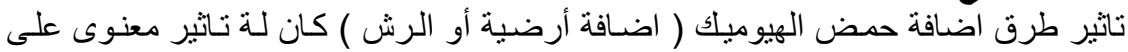

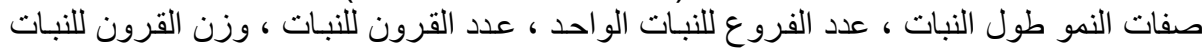

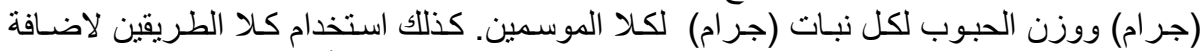

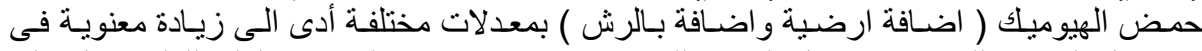

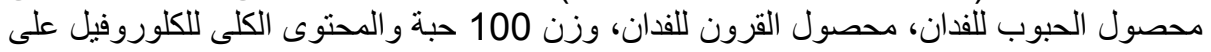

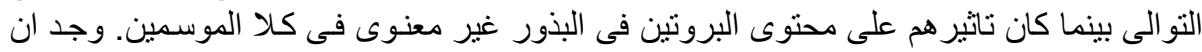

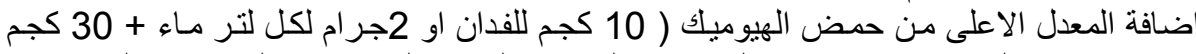

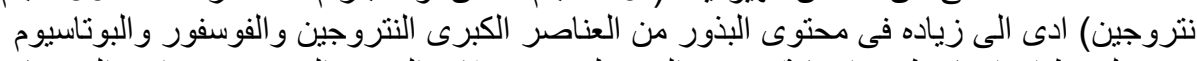

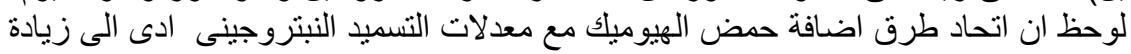

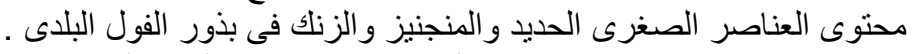

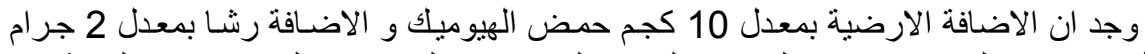

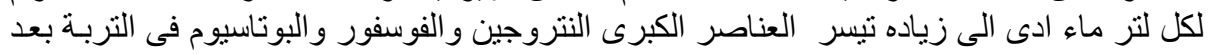

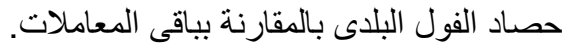

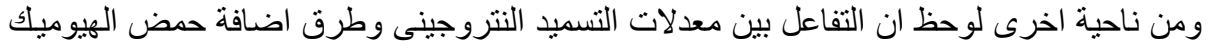

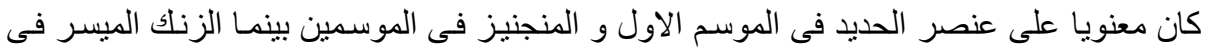

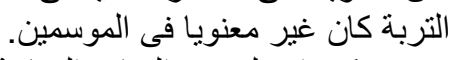

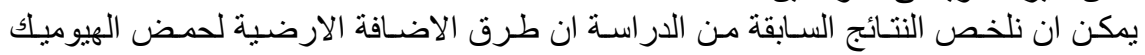

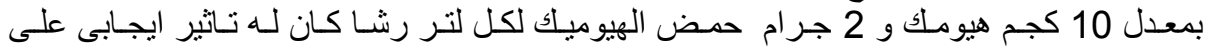
المحصول و المحتوى العناصر وتحسين بعض المكونات الكمبائية فى الفول و التربة الرملية. 
Dalia A. Sayed et al. 